\title{
The Effects of the Symptoms Experienced by Patients Undergoing Hemodialysis Treatment on their Comfort Levels
}

\author{
Rukiye Demir Dikmen ${ }^{1}$ (D) and Hakime Aslan, PhD ${ }^{2^{*}}$ \\ ${ }^{1}$ Lecturer, Healthcare Vocational School, Bingol University, Bingol, Turkey \\ ${ }^{2}$ Assistant Professor, Department of Nursing, Nursing Faculty, Inonu University, Malatya, Turkey \\ *Corresponding author: Hakime Aslan, PhD, Assistant Professor, Department of Nursing, Nursing Faculty, Inonu \\ University, Malatya, 44280, Turkey, Tel: +90-422-377-30-60, Fax: +90-422-341-02-19
}

\begin{abstract}
Background: Hemodialysis treatment has many physical or psychological symptoms such as anorexia, dryness of the mouth and discomfort. This study aims to the effects of symptoms in patients receiving hemodialysis treatment on their comfort levels.

Methods: This is cross-sectional study. The population of consisted of patients aged over 18 who received treatment at three hemodialysis centers in Elazig province and two in Bingol province. Sampling method was not used as it was aimed to reach the whole population. The research was carried out with 363 patients ( $84 \%$ of the population) meeting the research criteria. The data was collected between June-October 2019. Personal Information Form, Hemodialysis Comfort Scale (HDCS), and Dialysis Symptom Index (DSI) were used to obtain the data. Number, percentage, mean, standard deviation, and Linear regression analysis were used to analyze the data.
\end{abstract}

Results: The symptoms experienced by patients were found to be effective on their comfort levels and $R$ was 0.463 and $R^{2}$ was 0.215 . It was found that $21.5 \%$ of the total variance in the HDCS dependent variable was explained by the DSI total score and the result was found to be statistically significant $(p<0.001)$.

Conclusion: It was concluded that the symptoms experienced by patients had effects on their comfort levels.

\section{Keywords}

Hemodialysis, Comfort, Symptom, Nursing

\section{Abbreviations}

HD: Hemodialysis; RRT: Renal Replacement Therapy; TSD: Turkish Society of Nephrology; CRF: Chronic Renal Failure; DSI: Dialysis Symptom Index; HDCS: Hemodialysis Comfort Scale

\section{Introduction}

Hemodialysis (HD) treatment is the most preferred renal replacement therapy method by patients with end-stage renal failure in Turkey. According to the Turkish Society of Nephrology (TSD) Registry 2019 Report; the point prevalence of end-stage renal failure requiring renal replacement therapy (RRT) in Turkey was calculated as 988.4 per million populations as of the end of 2018 [1]. Hemodialysis treatment is one of the most preferred treatment methods in patients with endstage renal failure but it causes many symptoms that affect patients' quality of life on the other hand $[2,3]$.

Individuals receiving hemodialysis treatment have many physical or psychological symptoms such as anorexia, dryness of the mouth, diarrhea, constipation, nausea-vomiting, swelling in legs, muscle cramps, dizziness, drowsiness, restless legs syndrome, dry skin, coughing, pruritus, sleep disorders, concentration difficulties, chest and back pains, nervousness, sexual dysfunction, and discomfort $[3,4]$. In the study conducted by Zamanian and Kharameh (2015) with patients with end-stage renal failure in Iran, it was stated that the intensive physical symptom was fatigue (85.3\%), and the most common psychological symptom was restlessness (77.9\%) [5]. In the study conducted by Karabulutlu, et al. (2011), it was determined that patients experienced the most decrease in energy and fatigue since the onset of the disease and that these symptoms were associated with their disease [6]. In patients receiving hemodialysis treatment, along with frequent symptoms, many

Citation: Dikmen RD, Aslan H (2020) The Effects of the Symptoms Experienced by Patients Undergoing Hemodialysis Treatment on their Comfort Levels. J Clin Nephrol Ren Care 6:060. doi. org/10.23937/2572-3286/1510060

Accepted: December 15, 2020: Published: December 17, 2020

Copyright: (c) 2020 Dikmen RD, et al. This is an open-access article distributed under the terms of the Creative Commons Attribution License, which permits unrestricted use, distribution, and reproduction in any medium, provided the original author and source are credited. 
factors such as physical activity difficulties, change of eating habits, breakdown of family and friend relationships, restriction in social life, and negative impact of working life can negatively affect patients' quality of life and overall comfort [7].

Comfort, which is a very complex concept with many dimensions, has been studied by many theorists in nursing [8]. In nursing models, comfort is considered as a function of nursing and is deemed as one of the results of nursing care. It is the goal and desired outcome of nursing care today $[8,9]$. Besides, it is one of the most important elements of nursing care demanded by patients and their families [10]. Nurses should take appropriate nursing measures and take necessary interventions to increase the comfort of patients and to meet their comfort needs [11]. In the literature, it is seen that patient comfort is generally at a moderate level in hemodialysis patients, however, the number of studies evaluating comfort and associating comfort to clinical findings was not sufficient $[12,13]$. Based on the duty of providing patient comfort, which is an indispensable part of the nursing profession, emphasized by many nurse theorists, a study on the determination of the effects on symptoms and comfort levels in patients receiving hemodialysis treatment has not been found in the literature. Due to the symptoms caused by hemodialysis treatment in sick individuals, there may be changes in the comfort of individuals, the research result is expected to reveal these changes.

This study aims to the effects of symptoms in patients receiving hemodialysis treatment on their comfort levels.

\section{Methods}

\section{Type of research}

This is a cross-sectional study.

\section{Place and period of research}

The research was carried out in three hemodialysis centers in Elazig province and two hemodialysis centers located in Bingol province, in Turkey, between the dates of June-October 2019.

\section{The population and sample of research}

The population of research consisted of patients receiving hemodialysis treatment at three hemodialysis centers in Elazig province and two centers in Bingol province. Sampling method was not used as it was aimed to reach the whole population. The research was carried out with 363 hemodialysis patients meeting the research criteria and $84 \%$ of the population was reached.

\section{Inclusion and exclusion criteria of the study}

18 years and older patients without communication problems, receiving hemodialysis treatment for at least
6 months, and patients without a psychiatric diagnosis were taken in the study.

Patients who did not want to participate in the study, filled out the data collection form incomplete and became infected were excluded from the study.

\section{Data collection}

The data were collected between June-October 2019 by visiting the hemodialysis centers by the researcher. The patients received hemodialysis treatment 3 stages per week in two groups ( $1^{\text {st }}$ group; Monday-Wednesday-Friday and $2^{\text {nd }}$ group; Tuesday-Thursday-Saturday). The researcher visited hemodialysis centers every day of the week (except Sunday). During the period when patients receive hemodialysis treatment and while the patient feels comfortable, the data were collected by face-to-face interview technique.

Data collection tools: In the collection of data, "Personal Information Form", which was prepared by the researcher and contains the socio-demographic characteristics of patients receiving hemodialysis treatment and problems related to hemodialysis treatment, the "Dialysis Symptom Index" that aims to evaluate the symptoms due to hemodialysis, and the "Hemodialysis Comfort Scale" that aims to evaluate patients' comfort levels were used.

\section{Personal information form}

This form that was prepared by the researcher consists of descriptive information about patients undergoing hemodialysis such as age, gender, marital status, education level, employment status, economic status, number of children, meeting his/her own need independently, the presence of the person to assist during care and the person who provided assistance in care, duration of receiving hemodialysis treatment, existence of chronic disease other than chronic renal failure (CRF), and preexisting chronic disease. The personal information form consists of 13 questions, 3 of which are open-ended.

\section{Dialysis symptom index (DSI)}

The Dialysis Symptom Index was developed by Weisbord, et al. in 2004 to evaluate physical and emotional symptoms and their severity [14]. Turkish validity and reliability of the Dialysis Symptom Index was performed by Onsöz and Usta Yesilbakan (2013) and the Cronbach's alpha coefficient of the DSI was found as 0.83 [15].

DSI contains 30 symptoms that describe a particular physical or emotional symptom. The symptoms experienced in the last 7 days are answered as yes-no, where an answer of ' $n o$ ' indicates that there is no symptom and 'yes' shows that there is a symptom. If the answer of patient is 'yes', how much the symptom affects is evaluated with a 5-point Likert scale, where $1=$ none and $5=$ severe. The scores obtained are summed and 
the total scale score is obtained. This value varies between 0 and 150 . The closer the total scores reached to 150 points, the more the effect of the mentioned symptom increases [15]. In this study, the Cronbach's alpha of the scale was found 0.87 .

\section{Hemodialysis comfort scale (HDCS)}

Hemodialysis Comfort Scale (HDCS), which was developed by Sahin Orak, et al. in 2017 and validity and reliability was performed, is a reliable scale used to evaluate the comfort of patients receiving hemodialysis treatment for at least six months [12]. Hemodialysis Comfort Scale is a 5-point Likert-type scale and consists of 9 items and 2 subscales; the subscale "Relief" and subscale "Overcoming". $4^{\text {th }}$ item of this scale is scored reversely, whereas other items (1-3, 5-9) are scored as "never" 5 points and "always" 1 point. The least and highest scores that can be obtained from HDCS, subscale relief and subscale overcoming is 9.00-45.00; 3.00-15.00; and 7.00-30.00 respectively. The increase in the score shows that the comfort level increases. The Cronbach's Alpha values of the Hemodialysis Comfort Scale, subscale of overcoming and subscale of relief were found as $0.87,0.85$, and 0.88 respectively [12]. In this study, the Cronbach's Alpha of the scale was found as 0.74 .

\section{Data analysis}

Statistical analysis of the data was evaluated using SPSS 23 (Statistical Package for Social Science) package program. In the analysis of the data; number and percentage were used to evaluate the socio-demographic

Table 1: Socio-demographic characteristics of patients.

\begin{tabular}{|c|c|c|c|}
\hline Variables & $X \pm S D$ & Number & Percent (\%) \\
\hline Age & $59.17 \pm 14.84$ & & \\
\hline Number of Children & $3.77 \pm 2.69$ & & \\
\hline \multicolumn{4}{|l|}{ Duration to Undergo } \\
\hline Hemodialysis (Years) & $5.87 \pm 5.00$ & & \\
\hline \multicolumn{4}{|l|}{ Gender } \\
\hline Female & & 147 & 40.5 \\
\hline Male & & 216 & 59.5 \\
\hline \multicolumn{4}{|l|}{ Marital Status } \\
\hline Married & & 271 & 74.7 \\
\hline Single & & 37 & 10.2 \\
\hline Divorced & & 55 & 15.2 \\
\hline \multicolumn{4}{|l|}{ Educational Level } \\
\hline Non-literate & & 95 & 26.2 \\
\hline Literate & & 50 & 13.8 \\
\hline Primary & & 116 & 32.0 \\
\hline Secondary & & 75 & 20.7 \\
\hline Higher education and above & & 27 & 7.4 \\
\hline \multicolumn{4}{|l|}{ Economic status } \\
\hline High & & 26 & 7.2 \\
\hline Medium & & 138 & 38.0 \\
\hline Low & & 199 & 54.8 \\
\hline \multicolumn{4}{|l|}{ Employment status } \\
\hline Employed & & 17 & 4.7 \\
\hline Unemployed & & 185 & 51.0 \\
\hline Retired & & 161 & 44.4 \\
\hline \multicolumn{4}{|l|}{ Meeting his/her own needs } \\
\hline Able & & 250 & 68.9 \\
\hline Unable & & 113 & 31.1 \\
\hline \multicolumn{4}{|c|}{ The presence of chronic disease other than CRF } \\
\hline There is a chronic disease & & 285 & 78.5 \\
\hline There is no chronic disease & & 78 & 21.5 \\
\hline Total & & 363 & 100 \\
\hline
\end{tabular}

"More than one answer was given, $\mathrm{X} \pm \mathrm{SD}$ : Mean \pm Std. Deviation. 
characteristics of the patients, and standard deviation, mean, minimum and maximum values were used to evaluate the scores from the scales. The Cronbach $\alpha$ reliability coefficient was used to determine the internal consistency of HDCS and DSI scales. Linear regression analysis was used to evaluate the effects of hemodialysis symptoms on patients' comfort level. The suitability of the data to normal distribution was analyzed with Kolmogorov-Smirnov and Shapiro-Wilk tests, whereas non-parametric tests were used for non-normally distributed variables. In the research, statistical significance level was accepted as $p<0.05$.

\section{Ethical principles}

Prior to the data collection, ethical approval (Decision number: 2019/272) was obtained from the Ethics Committee of Scientific Research and Publication, Health Sciences of a University. Written institution consent was obtained from hemodialysis units. Permission was obtained from the authors via e-mail, who made the validity-reliability analysis for the scales used in the study. The individuals who will participate in the research were informed about the purpose of the research and what they are expected to perform, their written and verbal consent was obtained, and they were asked to sign the informed consent forms.

\section{Results}

The mean age of patients receiving hemodialysis treatment was $59.17 \pm 14.84$ years and the mean of their number of children was $3.77 \pm 2.69$. It was determined that $40.5 \%$ of the patients were female, $74.7 \%$ were married, $32 \%$ were primary school graduates, $54.8 \%$ of them had poor economic level, $51 \%$ were unemployed, and $68.9 \%$ could meet their own needs independently. The mean duration to undergo hemodialysis was 5.87 \pm 5.00 years and $78.5 \%$ of the patients were found to have an additional chronic disease in addition to chronic renal failure (Table 1 ).

It was observed that the patients received a total of $20.05 \pm 6.50$ points from the Hemodialysis Comfort Scale (HDRS), patients' comfort levels were found to be below the mid-level, they were found to get $5.25 \pm 2.66$ points and $14.79 \pm 4.63$ points from the subscale relief and subscale overcoming, respectively. Patients got $67.72 \pm 24.56$ points from the Dialysis Symptom Index and the symptoms experienced by them were found to be at moderate level (Table 2).

The dialysis-related symptoms experienced by patients were found to be intensive. Examining the symptoms experienced by patients undergoing hemodialysis treatment, it was found that the symptoms of a feeling of fatigue and decrease in energy ranked first among

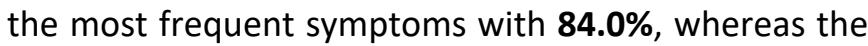
symptom of difficulty in concentrating ranked second with $\mathbf{5 1 . 8 \%}$. Besides, it was found that dry skin, nervousness, bone or joint pain, sleep-related symptoms, feeling sad, and numbness in feet were experienced intensely (Table 3).

The linear regression enter method was used to evaluate the effects of hemodialysis-related symptoms on patients' comfort level. It was found that the symptoms experienced by patients were effective on their comfort levels and $R=0.463, R^{2}=0.215$. It was found that $21.5 \%$ of the total variance in the HDCS dependent variable was explained by the Dialysis Symptom Index total score and the result was found to be statistically significant $(p<0.001)$. According to the result of the regression analysis, dialysis-related symptoms were found to have negative effects on the comfort levels of patients (B: -0.123) (Table 4).

Linear regression enter method was used to evaluate the effects of each of the dialysis-related symptoms independently on the comfort level of the patients. 30 dialysis-related symptoms were taken as the independent variables, while HDCS overall score was the dependent variable. It was found that many symptoms experienced by patients were effective on the comfort level of patients $\left(R=0.600, R^{2}=0.302\right)$ and the result was statistically significant $(p<0.001)$. It was determined that $30 \%$ of the total variance in the HDCS dependent variable was explained by these symptoms. The symptoms such as constipation, poor appetite, swelling in legs, dryness of the mouth, headache, being anxious, and feeling nervous were found to be effective on the comfort level (Table 5).

\section{Discussion}

In this study, DSI was used to evaluate the dialysis-related symptoms experienced by patients. It was found that, patients were experience a moderate level symptom. In the study carried out by Akgoz, et al., the symptoms experienced by patients were at moderate

Table 2: Distribution of hemodialysis comfort scale (HDRS) and dialysis symptom index (DSI) scores of patients receiving hemodialysis treatment.

\begin{tabular}{|l|l|l|l|}
\hline Scale & Min-Max Value that can be taken & Min-Max Value Obtained & X \pm SD \\
\hline Subscale Relief & $3.00-15.00$ & $2.00-10.00$ & $5.25 \pm 2.66$ \\
\hline Subscale Overcoming & $7.00-30.00$ & $7.00-30.00$ & $14.79 \pm 4.63$ \\
\hline HDCS Overall & $9.00-45.00$ & $9.00-36.00$ & $20.05 \pm 6.50$ \\
\hline DSI Overall & $0-150$ & $5.00-126.00$ & $67.72 \pm 24.56$ \\
\hline
\end{tabular}

Note: $X \pm S D:$ Mean \pm Std. Deviation. 
Table 3: Frequency of symptoms experienced by patients receiving hemodialysis treatment by dialysis symptom index.

\begin{tabular}{|c|c|c|c|c|c|c|c|c|c|c|c|c|}
\hline & \multicolumn{2}{|l|}{ No } & \multicolumn{2}{|c|}{ Never } & \multicolumn{2}{|c|}{ Rarely } & \multicolumn{2}{|c|}{ Sometimes } & \multicolumn{2}{|c|}{ Slightly } & \multicolumn{2}{|c|}{ Usually } \\
\hline & $\mathbf{N}$ & $\%$ & $\mathbf{N}$ & $\%$ & $\mathbf{N}$ & $\%$ & $\mathbf{N}$ & $\%$ & $\mathbf{N}$ & $\%$ & $\mathbf{N}$ & $\%$ \\
\hline Constipation & 141 & 38.8 & 22 & 6.1 & 28 & 7.7 & 115 & 31.7 & 6 & 1.7 & 50 & 13.8 \\
\hline Nausea & 167 & 46.0 & 21 & 5.8 & 47 & 12.9 & 99 & 27.3 & 3 & 0.8 & 26 & 7.2 \\
\hline Vomiting & 181 & 49.9 & 40 & 11.0 & 39 & 10.7 & 79 & 21.8 & 3 & 0.8 & 21 & 5.8 \\
\hline Diarrhea & 262 & 72.2 & 40 & 11.0 & 18 & 5.0 & 35 & 9.6 & 3 & 0.8 & 5 & 1.4 \\
\hline Poor appetite & 134 & 36.9 & 13 & 3.6 & 48 & 13.2 & 115 & 31.7 & 13 & 3.6 & 40 & 11.0 \\
\hline Muscle cramps & 71 & 19.6 & 13 & 3.6 & 43 & 11.8 & 130 & 35.8 & 8 & 2.2 & 98 & 27.0 \\
\hline Swelling in legs & 239 & 65.8 & 30 & 8.3 & 36 & 9.9 & 27 & 7.4 & 9 & 2.5 & 22 & 6.1 \\
\hline Dyspnea & 196 & 54.0 & 27 & 7.4 & 24 & 6.6 & 73 & 20.1 & 7 & 1.9 & 36 & 9.9 \\
\hline Drowsiness/Dizziness & 105 & 28.9 & 5 & 1.4 & 26 & 7.2 & 119 & 32.8 & 11 & 3.0 & 97 & 26.7 \\
\hline Restless legs syndrome & 269 & 74.1 & 23 & 6.3 & 17 & 4.7 & 14 & 3.9 & 3 & 0.8 & 37 & 10.2 \\
\hline $\begin{array}{l}\text { Numbness or tingling in } \\
\text { the feet }\end{array}$ & 102 & 28.1 & 26 & 7.2 & 22 & 6.1 & 67 & 18.5 & 8 & 2.2 & 138 & 38.0 \\
\hline $\begin{array}{l}\text { Feeling of fatigue and } \\
\text { decrease in energy }\end{array}$ & 7 & 1.9 & 2 & 0.6 & 15 & 4.1 & 27 & 7.4 & 7 & 1.9 & 305 & 84.0 \\
\hline Coughing & 238 & 65.6 & 29 & 8.0 & 39 & 10.7 & 37 & 10.2 & 1 & 0.3 & 19 & 5.2 \\
\hline Dryness of the mouth & 87 & 24.0 & 25 & 6.9 & 42 & 11.6 & 102 & 28.1 & 13 & 3.6 & 94 & 25.9 \\
\hline Bone or joint pain & 114 & 31.4 & 18 & 5.0 & 25 & 6.9 & 52 & 14.3 & 4 & 1.1 & 150 & 41.3 \\
\hline Chest pain & 248 & 68.3 & 30 & 8.3 & 23 & 6.3 & 36 & 9.9 & 8 & 2.2 & 18 & 5.0 \\
\hline Headache & 106 & 29.2 & 6 & 1.7 & 43 & 11.8 & 98 & 27.0 & 7 & 1.9 & 103 & 28.4 \\
\hline Muscle pain & 140 & 38.6 & 18 & 5.0 & 54 & 14.9 & 78 & 21.5 & 5 & 1.4 & 68 & 18.7 \\
\hline Concentration difficulties & 60 & 16.5 & 9 & 2.5 & 30 & 8.3 & 52 & 14.3 & 24 & 6.6 & 188 & 51.8 \\
\hline Dry skin & 3 & 0.8 & 14 & 3.9 & 161 & 44.4 & 96 & 26.4 & 38 & 10.5 & 50 & 13.8 \\
\hline Itching & 111 & 30.6 & 19 & 5.2 & 37 & 10.2 & 105 & 28.9 & 5 & 1.4 & 86 & 23.7 \\
\hline Being anxious & 102 & 28.1 & 21 & 5.8 & 76 & 20.9 & 41 & 11.3 & 21 & 5.8 & 102 & 28.1 \\
\hline Feeling nervous & 68 & 18.7 & 14 & 3.9 & 44 & 12.1 & 57 & 15.7 & 24 & 6.6 & 156 & 43.0 \\
\hline Difficulty falling asleep & 104 & 28.7 & 17 & 4.7 & 29 & 8.0 & 58 & 16.0 & 13 & 3.6 & 142 & 39.1 \\
\hline $\begin{array}{l}\text { Difficulty in maintaining } \\
\text { sleep }\end{array}$ & 102 & 28.1 & 14 & 3.9 & 29 & 8.0 & 67 & 18.5 & 11 & 3.0 & 140 & 38.6 \\
\hline Feeling uncomfortable & 63 & 17.4 & 18 & 5.0 & 64 & 17.6 & 65 & 17.9 & 33 & 9.1 & 120 & 33.1 \\
\hline Feeling sad & 40 & 11.0 & 19 & 5.2 & 53 & 14.6 & 78 & 21.5 & 33 & 9.1 & 140 & 38.6 \\
\hline Feeling anxious & 60 & 16.5 & 24 & 6.6 & 69 & 19.0 & 56 & 15.4 & 37 & 10.2 & 117 & 32.2 \\
\hline $\begin{array}{l}\text { Absence of sexual } \\
\text { appetite }\end{array}$ & 81 & 22.3 & 103 & 28.4 & 42 & 11.6 & 65 & 17.9 & 16 & 4.4 & 56 & 15.4 \\
\hline $\begin{array}{l}\text { Difficulty in getting sexual } \\
\text { satisfaction }\end{array}$ & 81 & 22.3 & 103 & 28.4 & 41 & 11.3 & 66 & 18.2 & 16 & 4.4 & 56 & 15.4 \\
\hline
\end{tabular}

Table 4: Examining the effects of dialysis-related symptoms on the comfort level of patients using regression analysis.

\begin{tabular}{|c|c|c|c|c|c|c|c|c|c|}
\hline \multirow[b]{2}{*}{ Model } & \multicolumn{2}{|c|}{$\begin{array}{l}\text { Unstandardized } \\
\text { Coefficients }\end{array}$} & \multicolumn{2}{|c|}{$\begin{array}{l}\text { Standardized } \\
\text { Coefficients }\end{array}$} & \multirow[b]{2}{*}{ Sig. } & \multirow[b]{2}{*}{$\mathbf{F}$} & \multirow[b]{2}{*}{ Sig } & \multirow[b]{2}{*}{$\mathbf{R}$} & \multirow[b]{2}{*}{$\mathbf{R}^{2}$} \\
\hline & B & SE & Beta & $\mathbf{t}$ & & & & & \\
\hline Constant & 28.360 & 0.889 & & 31.901 & 0.000 & & & & \\
\hline DSi Overall & -0.123 & 0.012 & -0.463 & -9.936 & 0.000 & 98.720 & $0.000^{\mathrm{b}}$ & $0.463^{a}$ & 0.215 \\
\hline
\end{tabular}

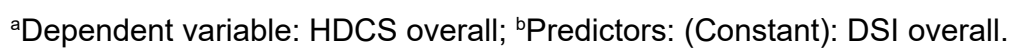

level [16], while in the study of Taskin Yilmaz, et al., the symptoms experienced were at low level [17]. In a study carried out in Iran, patients' symptoms were at high level [5]. In this research, factors such as advanced age of patients, long dialysis durations, and the presence of additional comorbid diseases in addition to CRF were thought to increase the symptoms experienced by them. 
Table 5: The effect of each of the dialysis-related symptoms independently on the comfort level of the patients.

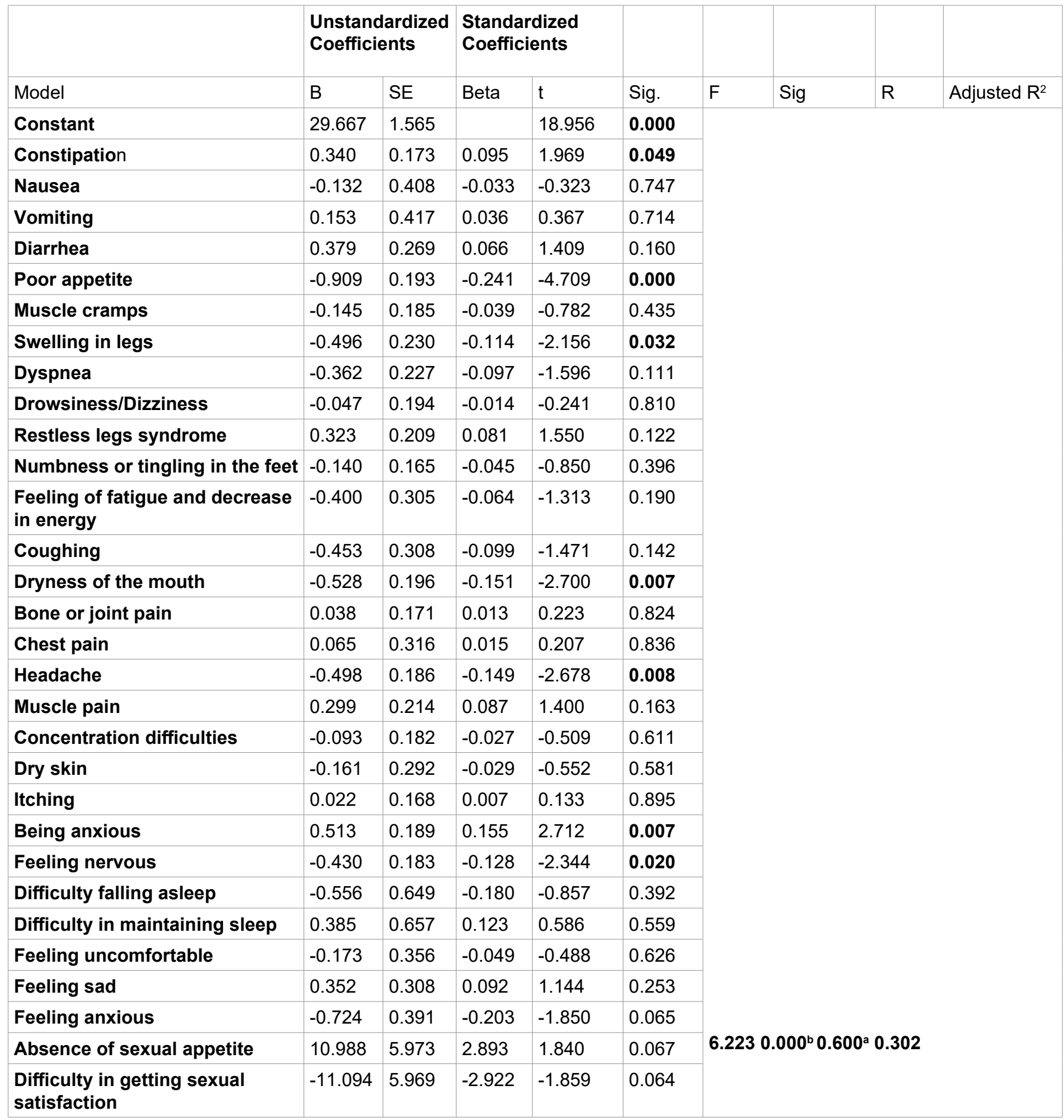

aDependent variable: HDCS Overall; bPredictors: (Constant), Constipation, Nausea, Vomiting, Diarrhea, Poor appetite, Muscle cramps, Swelling in legs, Dyspnea, Drowsiness/Dizziness, Restless leg syndrome, Numbness or tingling in the feet, Feeling of fatigue and decrease in energy, Coughing, Dryness of the mouth, Bone or joint pain, Chest pain, Headache, Muscle pain, Concentration difficulties, Dry skin, itching, Being anxious, Feeling nervous, Difficulty falling asleep, Difficulty in maintaining sleep, Feeling uncomfortable, Feeling sad, Feeling anxious, Absence of sexual appetite, Difficulty in getting sexual satisfaction.

In this research, patient's comfort level was the moderate level. Unlike our study, in their study investigating the comfort levels of HD patients, Sahin Orak, et al., found that patient's comfort level was found to be above the moderate level [12]. In their quasi-experimental study examining the effect of progressive relaxation exercises applied to HD patients on their comfort level, Turgay, et al., determined that patients in the both groups, the pre-test mean scores of HDCS were found to be moderate and compatible with our research find- ings [18]. There was a limited number of studies in the literature about the comfort levels of HD patients. In the studies conducted, it was found that the comfort levels of the patients were at a moderate level and our research result was compatible with the literature.

It was determined that the symptoms of a feeling of fatigue and decrease in energy ranked first among the most frequent symptoms with $84.0 \%$, whereas the symptom of difficulty in concentrating ranked second 
with $51.8 \%$ and dry skin ranked third with $44.4 \%$. Göris, et al. found that the most frequent symptoms experienced by patients undergoing dialysis were the feeling of fatigue and decrease in energy [19]. Different studies in the literature indicated that the feeling of fatigue and the decrease in energy were the symptoms frequently experienced $[5,20,21]$. Our research result was determined to be compatible with the literature. Factors such as the fact that the disease is chronic, being constantly dependent on hemodialysis machine, difficulty of diet, physical and psychological negative effects of the disease, as well as limited social relationships, and difficulties in maintaining daily life activities were among the reasons that the vast majority of patients experience the symptoms of fatigue intensely [21]. It was found that concentration difficulties ranked second among the most frequent experienced symptoms. In a study carried out in Sri Lanka using DSI, 59.9\% of the patients were found to experience the symptom of concentration difficulties [22]. Change in blood flow due to dialysis, and excessive fatigue is thought to be effective in the concentration difficulties symptom experienced by patients. Dry skin symptom was found to be ranked third among the symptoms experienced. Senanayake, et al. determined that $46.3 \%$ of the patients experienced dry skin symptom [22]. This result was found to be compatible with the results of our research. Factors such as the accumulation of residual substances in the skin due to failure to remove from the body, and the fact that skin loses its humidity due to advanced age are effective in experiencing dry skin and pruritus symptoms [23]. In our study, it is thought that the advanced age of the patients increases the frequency of dry skin symptom.

In our study, it was found that the dialysis-related symptoms negatively affect the comfort levels of the patients and the result was statistically significant ( $p<$ 0.001). The dialysis-related symptoms were found to affect the patient's comfort levels with a high rate as $21.5 \%$. In our study, it was found that the dialysis-related symptoms negatively affect the comfort levels of the patients and the result was statistically significant. Dialysis-related symptoms such as constipation, poor appetite, swelling in legs, dryness of the mouth, headache, being anxious, and feeling nervous were found to be effective on the comfort level $(p<0.05)$.

Many physical and psychological symptoms such as fatigue, muscle cramps, nervousness, pain, sleep disorders, discomfort, dry skin, poor appetite, nausea, and vomiting are seen in patients on hemodialysis treatment $[5,16]$ and these symptoms can negatively affect the self-care strength and vital activities of hemodialysis patients [24]. One of the most important problems experienced by hemodialysis patients and negatively affects their quality of life is sleep problems. Caliskan found that sleep disorder, which is based on pruritus symptoms in HD patients, affects patients' daily comfort levels negatively [25]. A study conducted in New York concluded that HD patients experience intense sleep disorders, and that sleep disorders affect the daily lives of patients [26]. Sleep problems in hemodialysis patients; It may be due to such as; pathophysiological reasons (fluid, acid-base and electrolyte disorders, anemia, iron deficiency, uremic toxins), lifestyle related reasons for HD implementation (HD sessions being too early or late hours, home away from the hemodialysis center, and the long waiting time to return home from the shuttle bus service), and psychological reasons (such as dependence on dialysis machine, depression, anxiety) [27]. These also negatively affect the comfort of the patients. Seeman, et al., determined that HD patients experience psychological disorders such as depression and anxiety [28]. In a study conducted with HD patients, it was found that $74.2 \%$ of the patients experienced pain after dialysis and the quality of life of those who experienced pain was low [29]. Sadigova, et al., found that $74.2 \%$ of patients receiving HD treatment experienced pain after dialysis, and those who experienced pain had poor quality of life [29].

It was found that dialysis patients need help at various levels while performing their daily life needs such as moving, shopping, participating in social activities, cooking, excretion, nutrition [30]. Göris found that HD treatment and its symptoms affect patients' family relationships and social lives negatively, including marital adjustment [19]. Sexual dysfunction is a common problem in CRF patients [31,32]. It was found that sexual disorders have negative effects on self-esteem in interpersonal relations [31,33]. In the studies conducted, it was found that the symptoms experienced negatively affect the quality of life of the patients, their work, marriage and family relations $[7,14,19]$. As can be seen from our research findings and literature studies, individuals who receive HD treatment experience many hemodialysis symptoms that negatively affect their daily life activities, make life difficult, make themselves dependent on someone else, and affect their comfort. The fact that hemodialysis treatment spreads over a few days of the week and the symptoms are intense negative affects the working lives and economic levels of the patients. In addition, symptoms such as fatigue/decreased energy, sleep disorders, sexual dysfunction, itching, and pain were affected patients' life routines and disrupt their comfort.

\section{Strength and limitations of the study}

During the hemodialysis treatment, patients report that they experience many symptoms. Many symptoms experienced with the DSI are considered together. The fact that this is the first study in the literature on how symptoms affect patient comfort is a strength aspect of the research. Besides, the limitation of the study is that patients receiving hemodialysis treatment in two provinces in eastern Turkey were included in the study. It is recommended to investigate the subject with larger 
sample groups. In addition, patients who did not speak Turkish could not be included in the study. This is another limitation of the research.

\section{Conclusion and Recommendations}

The HD symptoms experienced by the patients were found to be moderate. It was determined that the most common symptoms were feeling of fatigue and decrease in energy, concentration difficulties, dry skin, bone and joint pain, and sleep-related symptoms. Hemodialysis treatment-related symptoms were found to have negative effects on the comfort levels of patients. As understood from our research findings and literature studies, individuals receiving HD treatment experience many hemodialysis symptoms that negatively affect their daily life activities, make life difficult, make themselves dependent to someone else and affect their comfort. It is thought that the comfort levels of the patients will increase with the proper management of many symptoms experienced.

In line with these results:

- Providing training to nurses working at the haemodialysis centre on symptom management in order to alleviate the problems of fatigue and decreased energy, difficulty concentrating, dryness of the skin, bone joint pain and sleep that patients undergoing haemodialysis experience with intensity,

- Rearrangement of ergonomic conditions in haemodialysis units in order to increase the comfort level of patients,

- Nurses' evaluation of risk factors for symptoms affecting patients' comfort level,

- It is recommended that more comprehensive studies be conducted to understand the factors affecting the comfort level of patients.

\section{Acknowledgments}

The authors are grateful to the patients for participating in the study.

\section{Conflict of Interests}

The authors declare that they have no conflict of interests.

\section{Source of Support}

There are no financial support.

\section{Author Contributions}

Concept - A.H. D.D. R.; Design - A.H. D.D. R.; Supervision - A.H. D.D. R.; Resources - A.H. D.D. R.; Materials - A.H. D.D. R.; Data Collection and/or Processing - A.H. D.D. R.; Analysis and/or Interpretation - A.H. D.D. R.; Literature Search - A.H. D.D. R.; Writing Manuscript - A.H. D.D. R.; Critical Review - A.H. D.D. R.; Other - A.H. D.D. R.

\section{References}

1. Ministry of Health and Turkish Society of Nephrology Joint Report (2019) Registry of the nephrology, dialysis and transplantation in Turkey Registry 2018.

2. Terzi B (2017) Nursing care of patient who undergo hemofiltration in intensive care unit. Türk Nefroloji, Diyaliz ve Transplantasyon Hemşireleri Derneği Nefroloji Hemşireliği Dergisi 1: 12.

3. Durmaz Akyol A (2005) Kronik Böbrek Yetmezliği-Üriner Sistem Hastalıklarında Bakım, 1.Baski. İzmir, Nefroloji Diyaliz ve Transplantasyon Hemşireleri Derneği Yayinlari, 112-150.

4. Murtagh FE, Addington-Hall J, Higginson IJ (2007) The prevalence of symptoms in end-stage renal disease: A systematic review. Adv Chronic Kidney Dis 14: 82-99.

5. Zamanian H, Kharameh ZT (2014) Translation and psychometric properties of the Persian version of the dialysis symptom index in hemodialysis patients. Nephrourol Mon 7: e23152.

6. Okanli A, Karabulutlu YE (2011) Hemodiyaliz hastalarında hastalik algisinin değerlendirilmesi. Anadolu Hemşirelik ve Sağlik Bilimleri Dergisi 14: 25-31.

7. Weisbord SD, Fried LF, Arnold RM, Fine MJ, Levenson DJ, et al. (2005) Prevalence, severity, and importance of physical and emotional symptoms in chronic hemodialysis patients. J Am Soc Nephrol 16: 2487-2494.

8. Kolcaba KY, Kolcaba RJ (1991) An analysis of the concept of comfort. J Adv Nurs 16: 1301-1310.

9. Malinowski A, Stamler LL (2002) Comfort: Exploration of the concept in nursing. J Adv Nurs 39: 599-606.

10. Kim SK, Kwon SH (2007) Comfort and quality of life of cancer patients. Asian Nurs Res (Korean Soc Nurs Sci) 1: 125135.

11. Rousseaux M, Perennou D (2004) Comfort care in severely disabled multiple sclerosis patients. J Neurol Sci 222: 3948.

12. Şahin Orak N, Çinar Pakyüz S, Kartal A (2017) Ölçek Geliştirme Çalişmasi: Hemodiyaliz Hastalarinda Konfor. Türk Nefroloji, Diyaliz ve Transplantasyon Hemşireleri Derneği Nefroloji Hemşireliği Dergisi 12: 68-77.

13. Tabiee S, Momeni A, Saadatjoo SA (2017) The effects of comfort-based interventions (back massage and patient and family education) on the level of comfort among hemodialysis patients. Mood Care J 14: e64687.

14. Weisbord SD, Fried LF, Arnold RM, Rotondi AJ, Fine MJ, et al. (2004) Development of a symptom assessment instrument for chronic hemodialysis patients: The dialysis symptom index. J Pain Symptom Manage 27: 226-237.

15. Önsöz HB, Usta Yeşilbalkan Ö (2013) Reliability and validity of the Turkish version of the dialysis symptom index in chronic hemodialysis patients. Turk Neph Dial Transpl 22: 60-67.

16. Akgöz N, Arslan S (2017) Hemodiyaliz tedavisi alan hastalarda yaşanan semptomlarin incelenmesi. Türk Nefroloji, Diyaliz ve Transplantasyon Hemşireleri Derneği Nefroloji Hemşireliği Dergisi 1: 20-28.

17. Taşkin Yilmaz F, Sert H, Karakoç Kumsar A, Aygin D, Sipahi S, et al. (2020) Hemodiyaliz tedavisi alan hastaların umut düzeyleri, semptom kontrolü ve tedaviye uyumlarinin değerlendirilmesi. ACU Sağlik Bil Derg 11: 35-43. 
18. Turgay G, Özdemir Eler Ç, Ökdem Ş, Kaya S (2020) Hemodiyaliz hastalarinda progresif gevşeme egzersizinin konfor düzeyine etkisi. Nefroloji Hemşireliği Dergisi 15: 16-22.

19. Göriş S, Ceyhan Ö, Taşçi S, Doğan N (2016) Do symptoms related to hemodialysis affect marital adjustment? Sex Disabil 34: 63-73.

20. Caplin B, Kumar S, Davenport A (2011) Patients' perspective of haemodialysis-associated symptoms. Nephrol Dial Transplant 26: 2656-2663.

21. Yurtsever S, Bedük T (2003) Hemodiyaliz uygulanan bireylerde yorgunluğun değerlendirilmesi. Hemşirelikte Araştirma Geliştirme Dergisi 8: 3-10.

22. Senanayake S, Gunawardena N, Palihawadana P, Bandara P, Haniffa R, et al. (2017) Symptom burden in chronic kidney disease; a population based cross sectional study. BMC Nephrology 18: 228.

23. Kavurmaci M, Tan M (2015) Üremik kaşinti ve hemşirelik bakimi. Anadolu Hemşirelik ve Sağlik Bilimleri Dergisi 18: 57-62.

24. Akin S, Mendi B, Ozturk B, Cinper C, Durna Z (2014) Assessment of relationship between self-care and fatigue and loneliness in hemodialysis patients. J Clin Nurs 23: 856864.

25. Çalışkan T (2018) Hemodiyaliz Tedavisi Alan ve Almayan Üremik Hastalarda Kaşıntı Konforu Etkiler mi? Manisa Celal Bayar Üniversitesi.
26. Maung S, Sara AE, Cohen D, Chapman C, Saggi S, et al. (2017) Sleep disturbance and depressive affect in patients treated with haemodialysis. J Ren Care 43: 60-66.

27. Tosun N, Kalender N, Cinar FI, Bagcivan G, Yenicesu M, et al. (2015) Relationship between dialysis adequacy and sleep quality in haemodialysis patients. J Clin Nurs 24: 2936-2944.

28. Semaan V, Noureddine S, Farhood L (2018) Prevalence of depression and anxiety in end-stage renal disease: $A$ survey of patients undergoing hemodialysis. Appl Nurs Res 43: 80-85.

29. Sadigova E, Ozkurt S, Yalçin AU (2020) Pain assessment in hemodialysis patients. Cureus 12: e6903.

30. Alagöz Mamaş H, Aydin Avci İ (2018) Kronik böbrek yetmezliği olan hastalarin günlük yaşam aktivitelerinin ve evde bakim gereksinimlerinin belirlenmesi. SETSCI Conference Indexing System 3: 1443-1453.

31. Barroso LVS, Miranda EP, Cruz NI, Medeiros MAS, Araujo ACO, et al. (2008) Analysis of sexual function in kidney transplanted men. Transplant Proc 40: 3489-3491.

32. Balioti A, Bristogiannis G (2007) Sexual dysfunction in patients with chronic kidney disease. Info Urology 47: 10-12.

33. Coelho-Marques FZ, Wagner MB, Poli de Figueiredo CE, d'Avila DO (2006) Quality of life and sexuality in chronic dialysis female patients. Int J Import Res 18: 539-543. 